Electronic conduction in rutile $\left(\mathrm{TiO}_{2}\right), \mathrm{H}, \mathrm{P}, \mathrm{R}$. Frederikse, W. R. Hosler, and J. S. Becker, Proc. Intern. Conf. Semiconductor Phys., Prague, Czechoslovakia, pp. 868-871 (1960).

Structure and photodetachment spectrum of the atomic carbon negative ion, M. L. Seman and L. M. Branscomb, Phys. Rev. 125, No. 5, 1602-1608 (Mar. 1962).

Modulated photoelectric measurement of vibration, V. A. Schmidt, S. Edelman, E. R. Smith, and E. T. Pierce, J. Acoust. Soc. Am. 34, No. 4, 455-458 (Apr. 1962).

A high mode tunable cavity for microwave-gas interactions, A. J. Estin, Rev. Sci. Instr. 33, 369-371 (Mar. 1962).

Utilization of tritium and carbon-14 in studies of isotope effects, H.S. Isbell, H. L. Frush, and L. T. Sniegoski, Book, Tritium in the Physical and Biological Sciences II, pp. 94-101 (International Atomic Energy Agency, Vienna, Austria, 1962).

A statistical comparison of the wearing characteristics of two types of dollar notes, E. B. Randall, Jr., and J. Mandel, Materials Research and Standards (ASTM Bull.) 2, No. 1, 17-20 (Jan. 1962).

Study of the effect of large aperture on the performance of an Ebert spectrometer, L. R. Megill and L. Doppleman, J. Opt. Soc. Am. 52, No. 3, 258-261 (Mar. 1962).

Prediction of pressure drop in two-phase single-component fluid flow, M. R. Hatch and R. B. Jacobs, A.I.Ch.E. Journal 8, No. 1, 18-25 (Mar. 1962).

Potential heat: A method for measuring the heat release of materials in building fires, J. J. Loftus, D. Gross, and A. F. Robertson, Am. Soc. Testing Materials Proc. 61, 13361348 (June 1961).

Comparison of standard and microtests for international rubber hardness, R. D. Stiehler and F. L. Roth, Materials Research and Standards (ASTM Bull.) $\boldsymbol{2}$, No. 5, 388-391 (May 1962).

Comments on "effects of ultrahigh pressures on glass", C. E. Weir and S. Spinner, J. Am. Ceram. Soc. 45, No. 4, 196 (Apr. 1962).
The "vicious cycle" in secondary batteries - a mathematica I approach, W. G. Eicke, Jr., J. Electrochem. Soc. 109, No. 5, 364-368 (May 1962).

Communication between man and machine, S. N. Alexander and J. E. Karlin, Proc. IRE 50, No. 5, 1124-1128 (May 1962).

Entropies, heats of sublimation and dissociation energies of the cesium halides, M. D. Scheer and J. Fine, J. Chem. Phys. 36, No. 6, 1647-1653 (Mar. 15, 1962).

The radio refractive index of air, B. R. Bean, Proc. IRE 50, No. 3, 260-273 (Mar. 1962).

The reflection of logistics in electronic computer design, E. W. Cannon, Naval Research Logistics Quart. 7, 365-371 (1960).

Deactivation of $\mathrm{Hg}\left(6^{3} \mathrm{P}_{1}\right)$ by $\mathrm{CO}$ and $\mathrm{N}_{2}, \mathrm{M}$. D. Scheer and J. Fine, J. Chem. Phys. 36, No. 5, 1264-1267 (Mar. 1962). Variability of spectral tristimulus values, I. Nimeroff, J. Opt. Soc. Am. 52, No. 6, 685-691 (June 1962).

Emission flame photometry, M. Margoshes, Anal. Chem. 34, No. 5, 221R-224R (Apr. 1962).

Preparation of and electroplating on uranium, D. E. Couch, Plating 49, No. 4, 363-367 (Apr. 1962).

Tungsten helical-spring microbalance, S. L. Madorsky, Vacuum Microbalance Techniques 2, 47-57 (Plenum Press, Inc., New York, N.Y., 1962).

Thermal explosives: adiabatic self-heating of explosive and propellants, D. Gross and A. B. Amster, Eighth Symp. (Intern.) on Combustion, pp. 728-734 (The Williams and Wilkins Co., Baltimore, Md., 1962).

*Publications for which a price is indicated (except for Technical Notes) are available only from the Superintendent of Documents, U.S. Government Printing Office, Washington 25, D.C. (foreign postage, one-fourth additional). Technical Notes are available only from the Offices of Technical Services, U.S. Department of Commerce, Washington 25, D.C. (order by PB number). Reprints from outside journals and the NBS Journat of Research may often be obtained directly from the authors.

\title{
ANNOUNCEMENT
}

\section{Fundamental Change in the CRPL-D Series, Basic Radio Propagation Predictions}

A fundamental change in the form and content of the CRPL-D series, Basic Radio Propagation Predictions, will be made in January 1963. The first of the new form of predictions will be CRPL-D221, issued in January 1963, containing predictions for April 1963. Beginning with that issue, the predictions will be prepared by a method of numerical mapping using a high speed electronic computer. This method was developed by W. B. Jones and R. M. Gallet of CRPL. Instructions for use of the new predictions will be issued concurrently.

The new format will include tables of coefficients which, when used as input data with a suitable program, make possible the efficient use of a computer for calculation of detailed high frequency radio propagation predictions for any application.

World prediction maps for every even hour, Universal Time, will be provided for those who do not have the use of a computer. These will be actual world maps of zero-MUF and 4000-MUF, instead of the time charts for four zones appearing in previous issues. Methods for using the new maps will be similar to methods for using the former time charts. The D-series predictions will continue to be issued through the Superintendent of Documents, U.S. Government Printing Office, Washington 25, D.C. No change in subscription price is planned. 